\title{
Piotr Plichta (D)
}

Uniwersytet Pedagogiczny im. KEN w Krakowie piotr.plichta@up.krakow.pl

\section{Przekład elementów awangardowych w polskich i rosyjskich tłumaczeniach wierszy Charlesa Bukowskiego}

Pojęcie poetyki lub estetyki awangardowej najczęściej odnosi się do artystyczno-ideowej formy właściwej tym ruchom w literaturze i sztuce, które powstały w Europie na początku XX stulecia i radykalnie kontestowały utarte formy uczestnictwa w kulturze i życiu społecznym - w Polsce ich celem było zwłaszcza przewalczenie spuścizny romantycznej i postromantycznej. Jednak uchwycenie samej istoty awangardowości nie jest łatwe. Truizmem będzie przypomnieć, że słowo „awangarda” ma militarne korzenie i pierwotnie oznaczało straż przednią oddziału wojskowego odpowiedzialną za rozpoznanie nieznanego (bywa, że i wrogiego) terenu. W Słowniku języka polskiego pod redakcją Witolda Doroszewskiego ten aspekt przecierania siłą nowych szlaków, wybiegania naprzód w stosunku do większości (bywa, że wbrew jej woli) jest jeszcze silnie zaznaczony: przymiotnik ,awangardowy” thumaczy się tam jako ,przodujący, nowatorski, prekursorski, postępowy” [Doroszewski 1958-1969]. We współczesnej internetowej wersji Stownika języka polskiego $P W N$ ten sam wyraz opisany został ogólniej jako „wprowadzający coś nowego w danej dziedzinie" [SJP PWN]. Już porównanie 
tych haseł encyklopedycznych pokazuje, że rozumienie awangardowości na przestrzeni lat uległo znamiennemu przesunięciu - nacisk na sam fakt przodownictwa i prekursorstwa $\mathrm{w}$ danej dziedzinie, którego widomym skutkiem jest rozprzestrzeniający się $\mathrm{w}$ jej granicach postęp, zastąpiło skupienie się raczej na indywidualnym, a przy tym skutecznym (i w gruncie rzeczy utylitarnie rozumianym) akcie wprowadzenia do obiegu kultury elementów wcześniej jej nieznanych. Z kolei ciekawa definicja podawana przez Oxford Living English Dictionaries brzmi:,,favouring or introducing new and experimental ideas and methods" [Lexico]. Warto zwrócić uwagę na to, że w przytoczonym angielskim ujęciu zjawiska awangardowość została celnie powiązana z podejmowaniem różnorakich eksperymentów i wyborów ideowych obarczonych ryzykiem (słowo „eksperyment” etymologicznie wywodzi się z praindoeuropejskiego rdzenia *per- oznaczającego m.in. podejmowanie ryzyka [Etymonline]. Laciński wyraz ,,peritus" przechował ambiwalencję tego rdzenia, gdyż z jednej strony oznacza kogoś uzdolnionego i doświadczonego, ale z drugiej może odnosić się do człowieka, który poległ, lub do czegoś zniszczonego), ale niekoniecznie musi to iść w parze z samodzielnym, twórczym wprowadzeniem nowych tropów myślowych czy strategii. Otóż cechy awangardowości całkowicie spełnia tutaj także bierna akceptacja szerszego fenomenu - indywidualna bądź grupowa preferencja (favouring) dla stosowania metodologicznych lub umysłowych nowinek.

Szukając zatem kryterium, które pozwalałoby stwierdzić, czy poetyka lub estetyka danego tekstu naprawdę jest awangardowa, warto sięgnąć do teorii polisystemowej opracowanej w latach sześćdziesiątych i siedemdziesiątych XX wieku przez grupę badaczy izraelskich, głównie Itamara Even-Zohara i Gideona Touriego [Munday 2001: 108-109]. Podstawowym jej pojęciem jest repertuar, czyli dynamiczny konglomerat zasad i innych elementów, które „rządzą produkcją tekstów w zmieniających się warunkach w różnych epokach i kulturach" [Plichta 2013: 160]. Jako że repertuar jest hierarchicznie ustrukturyzowany i wykazuje wyraźną tendencję do posiadania kanonu i peryferii, między którymi na przestrzeni czasu przemieszczają się poetyki, dzieła literackie, stosunek do określonej tradycji, typowe poglądy filozoficzne, podejście do religii itd., można by zaryzykować tezę, że w danym momencie historycznym awangardowość będzie polegała na zupełnie celowym i świadomym umieszczeniu pewnych, jeśli nie wszystkich, cech poetyki lub estetyki nowego tekstu na peryferiach systemu i w jawnej, a często wyzywającej opozycji 
wobec wymagań dominującego w nim kanonu; decyzjami podobnego rodzaju jest zazwyczaj przewrót wersyfikacyjny czy formalny oraz naruszanie rozmaitych lingwistycznych i kulturowych tabu, co objawia się np. przez użycie drastycznego obrazowania lub niskiego, potocznego rejestru języka.

Zjawisko to stanowi ostatecznie źródło licznych trudności dla przekładających. Nieuchronna diachroniczna ewolucja polisystemu kultury źródłowej nie obchodzi się bowiem jednakowo ze wszystkimi wyznacznikami awangardowości: niektóre takie elementy nawet po wielu latach zachowują swój wywrotowy potencjał, podczas gdy inne blakną, przesuwając się w stronę rodzimego kanonu, a ich peryferyjność przestaje być dla odbiorców odczuwalna. Gdy więc mamy do czynienia $\mathrm{z}$ thumaczeniem dzieła literackiego, którego ważnym tworzywem są w oryginale pewne składniki awangardowej poetyki czy estetyki, zderzenie polisystemu kultury źródłowej i docelowej należy do szczególnie skomplikowanych procesów. Wymaga to od tłumacza głębokiego zrozumienia każdego aspektu przekładanego tekstu - w tym jego miejsca w źródłowym polisystemie i trafnej oceny, do jakiego stopnia istotne będzie znalezienie przekładowego ekwiwalentu sytuującego się na peryferiach polisystemu kultury docelowej.

Widać to dobrze w tekście polskich i rosyjskich przekładów poezji Charlesa Bukowskiego (1920-1994). Poeta ten, którego otacza silna autobiograficzna legenda, generacyjnie mógłby przynależeć do pokolenia bitników, jak Jack Kerouac czy Alen Ginsberg, niemniej sam oficjalnie odżegnywał się od związków z wszelkimi awangardowymi ruchami, $\mathrm{z}$ ich ideami nonkonformizmu, swobody twórczej czy anarchistycznego indywidualizmu. Jest autorem kilku powieści oraz ogromnej liczby wierszy, które tworzył przez całe życie, nie troszcząc się zbytnio o ich losy. Miał podobno w zwyczaju pisać na maszynie tylko jedną kopię danego wiersza, bez użycia kalki, a następnie wysyłać do jakiegoś czasopisma celem publikacji. Wskutek takiej praktyki - świetnie pasującej do wizerunku literackiego outsidera - spora część jego poetyckiego dorobku przepadła [Jarniewicz 2004: 263]. Niektóre doświadczenia Bukowskiego z recepcją własnej poezji noszą zresztą posmak szyderczej ironii losu. Przykładowo według Howarda Sounesa kiedy wczesne wiersze poety ukazały się w jednym z prestiżowych czasopism, jego znienawidzony ojciec (noszący to samo imię i nazwisko) natychmiast rozgłosił w muzeum, 
gdzie właśnie pracował jako strażnik, że to on jest ich autorem, i otrzymał za to awans zawodowy [Sounes 2010: 27].

Tak czy inaczej, liryki i powieści Bukowskiego kojarzone są przede wszystkim z brudem i dnem życia - a więc z nieudawaną perspektywą społecznego wyrzutka przynależącego do dołów społecznych, którego dnie wypełniają głównie doświadczenia różnorakiej przemocy i nałogowy alkoholizm. Autor ten, nie stroniąc od skatologii i leksykalnie i gramatycznie zdegradowanych warstw języka [Jarniewicz 2004: 263], opisuje więc świat tanich spelun i ciągle zmieniających się kobiet oraz realia nędznie płatnej, poniżającej i odmóżdżającej pracy. Paradoks polega jednak na tym, że te elementy, jakkolwiek charakterystyczne i niewątpliwie przynależące do peryferii polisystemu amerykańskiej kultury przynajmniej od czasów drastycznych opowiadań Ambrose'a Bierce'a, wydają się niejedynymi awangardowymi wyznacznikami poezji Bukowskiego. Pod tym względem o wiele ważniejsza i bardziej szokująca dla odbiorców jest postawa artysty i jego bohaterów wobec świata. Jerzy Jarniewicz trafnie ujmuje jej istotę, pisząc, że właściwy temat poezji Bukowskiego stanowi nie alkoholiczne imaginarium, lecz przemożna potęga czasu, który jest skaźcą nie tylko wszelkiego ciała, lecz także pamięci, sprawia bowiem, że życie staje się pędzącą, bezładną i chaotyczną plątaniną obrazów i wydarzeń, z których nie sposób wydobyć żadnej rzetelnej konkluzji - te istniejące okazują się tylko społecznie przyjętymi, lecz bezwartościowymi kalkami [ibidem: 265-267]. Aby to w sposób zaskakujący, acz dobitny unaocznić czytelnikowi, poetyka wierszy Bukowskiego zasadza się w dużej mierze na dwóch chwytach. Po pierwsze, pisarz operuje elementami leksykalnymi i gramatycznymi podkreślającymi bezosobowość wszystkiego, co się zdarza i zachodzi; idzie to parze z tymi cechami angielszczyzny, które czynią ją językiem skłonnym do chłodnej abstrakcji. Po drugie, stosuje technikę budowania wiersza z wykorzystaniem smakowitej, często podszytej wulgarnością anegdoty, która zdaje się przemyślnie skonstruowana i przynosi czytelnikowi obietnicę jakiejś ciekawej, mocnej pointy - ta zaś rzeczywiście następuje, ale okazuje się całkiem pusta wewnętrznie, gdyż tak naprawdę niczego nie domyka ani nie wyjaśnia ${ }^{1}$. Zdaniem Jarniewicza:

Marcin Baran uważa, że ta skłonność Bukowskiego do wyraźnych point często razi nienaturalnością, gdyż przystoi poetom intelektu, a nie „bezpretensjonalnemu poecie niezależnemu" [Baran 2005: 443]. 
W świecie Bukowskiego takiego domknięcia nie ma i być nie może. Te naładowane podskórnym dramatyzmem opowiastki [...] podcięte są zaskakującym gestem obojętności człowieka, który w ten sposób odmawia uczestnictwa $\mathrm{w}[\ldots]$ do cna ogranych spektaklach i nie zgadza się na wysnuwanie jakichkolwiek morałów czy sądów ogólnych [...] Podobnie jak Konsul z Pod wulkanem Lowry'ego bohater wierszy Bukowskiego nie interweniuje, pozwala, by rzeczywistość mu się przydarzała, bo czuje, że interwencja niczego nie zmieni, co najwyżej zaspokoi naszą próżność, pozwalając nam obłudnie tkwić w przekonaniu, że coś jeszcze chcemy i potrafimy w tym świecie załatwić [ibidem: 265-266].

W tym odrzuceniu pointy kryje się być może głębiej gest sprzeciwu artysty wobec pewnego zjawiska, które stanowi charakterystyczny wyraz religijnego myślenia, jakim podszyta jest amerykańska kultura - obsesji poszukiwania znaków własnego wybraństwa. Otóż - jak to świetnie pokazał John Stachniewski w książce The Persecutory Imagination. English Puritanism and the Literature of Religious Despair [Stachniewski 1991] - w angielskim protestantyzmie już od XVI stulecia istniał ważny nurt teologiczny, który w kontrze do stanowiska oficjalnego Kościoła państwowego przyjmował o wiele radykalniejszą doktrynę o łasce i zbawieniu. Zgodnie $\mathrm{z}$ nią liczba odkupionych jest nader niewielka w stosunku do rzesz skazanych na piekło. Co ważniejsze, zbawienie lub potępienie wieczne jednostki dokonuje się obscuro consilio, przez całkowicie arbitralny wyrok Boga, na który nie mają żadnego wpływu uczynki ani nawet wewnętrzna postawa człowieka. Przyjęcie tak skrajnej wykładni wiary mogło rodzić rozpacz i lęk, ale najciekawszym tego efektem stało się kompulsywne poszukiwanie zewnętrznych znaków mogących wskazywać, w którą stronę przechyla się boski wyrok u danego człowieka. Zwłaszcza w XVII stuleciu powstały całe książki katalogujące tego rodzaju omina redemptionis vel damnationis, a głęboko kalwińskie podstawy takiego myślenia sprawiły, że jednym z najważniejszych wskaźników przychylności Stwórcy stała się jawna, materialna pomyślność i sprawczość. Trzeba dodać, że takie poglądy były szczególnie rozpowszechnione w ruchach nonkonformistycznych i na dolnym szczeblu społecznym Anglii, a więc w środowisku, skąd wywodziła się znakomita większość ludzi, którzy dokonali wczesnej kolonizacji Ameryki i położyli niewidzialne podwaliny jej kultury. Ten religijny w swych podstawach wzorzec zachowania, mimo całej ewolucji, jakiej podlegała i podlega rzeczywistość, 
przetrwał i tkwi do dziś w zbiorowej podświadomości amerykańskiej, stanowiąc istotny, choć często słabo uświadomiony składnik jej mitu aktywnego indywidualizmu; wychodzi on niekiedy na powierzchnię w dość zaskakujących okolicznościach ${ }^{2}$.

Awangardowość i peryferyjność Bukowskiego w amerykańskiej kulturze wynika po części z odrzucenia takich hektycznych poszukiwań wielkiego indywidualnego uzasadnienia: pisarz wydaje się jak najdalszy od takiej postawy, a bliski czemuś w rodzaju stoickiej ataraksji, zdolności do osiągnięcia wewnętrznego spokoju przez wyzbycie się przesadnych pragnień i lęków, a także powstrzymanie się od osądów względem spraw ludzkich [Nerczuk 2006: 22]. Nie ma to jednak nic wspólnego z akademicką filozofią i modą na duchowość Wschodu, typowymi dla pokolenia beatników - wypływa raczej z bardzo osobistej introwersji oraz postawy współodczuwania z prostymi ludźmi, nabytej przez długą przynależność do społecznego dołu. Nie jest przypadkiem, że najlepsze wiersze Bukowskiego - takie jak Tragedia liści, w którym podmiot liryczny budzi się po ciągu alkoholowym $\mathrm{w}$ absolutnie pustym i cichym mieszkaniu, by skonfrontować się z groteskową postacią gospodyni domu, która machaniem rękami i wrzaskiem domaga się czynszu - oparte są na złożonym zderzeniu fizycznego lub metafizycznego ruchu oraz bezruchu, stagnacji. Oddanie tego kontrastu w przekładzie wymaga jednak drobiazgowej analizy tekstu źródłowego i subtelnych środków, które stosuje artysta, budując sytuację liryczną.

Spośród przekładających poezje Bukowskiego na język polski na uwagę niewątpliwie zasługuje Piotr Madej (1969-2008), przedwcześnie zmarły tłumacz i pedagog związany z Sandomierzem [cf. Madej 2018]. Choć jego przekłady są ciekawe i rzetelne, wydaje się, że właśnie obecny $\mathrm{w}$ angielskich oryginałach Bukowskiego bezosobowy charakter przemijania stanowił dla niego bardzo duże wyzwanie, a miejscami wręcz tłumaczeniową pułapkę. W pierwszej strofoidzie bardzo smutnego i przejmującego wiersza o wiele mówiącym tytule Dreamlessly Bukowski pisze:

2 Bardzo interesującym jego przykładem może być serial sensacyjny Breaking Bad, gdzie Walter White, prowincjonalny nauczyciel chemii, w obliczu rychłej śmierci na raka płuc decyduje się rozpocząc karierę bezwzględnego producenta narkotyków. Jego działania można odczytać głębiej jako pewne znamiona nieuświadomionej obsesji sprawdzenia się, poszukiwania znaków wskazujących na własny los pośmiertny. 
Old, grey-haired waitresses

in cafes at night

have given it up

and as I walk down sidewalks of

light and look into windows

of nursing homes

I can see that it is no longer

\section{with them}

I see people sitting on park benches

and I can see by the way they

sit and look

that it is gone ${ }^{3}$ [Bukowski 1974: 229].

Zaimek it jest w tym kontekście bardzo istotny, gdyż służy podkreśleniu niewidzialnej i obezwładniającej siły czasu. Bukowski z premedytacją powtarza go trzykrotnie, przez co nadaje całości posmak nihilistycznej, lecz surowo brzmiącej gnomy. Fragment ten domaga się zatem od tłumacza rezygnacji z wszelkiej ozdobności, a najlepiej przełożenia go za pomocą bezosobowych konstrukcji gramatycznych i z zachowaniem trzykrotnego powtórzenia znacznika kohezji tekstowej. Tymczasem u Madeja, który tytuł liryku oddał jako Bez marzeń, czytamy:

stare, siwe kelnerki

w kawiarniach w nocy

już się poddały

i kiedy idę oświetlonym

chodnikiem i zaglądam do okien

przytułków

widzę że czar już

prysl

widzę ludzi siedzących na ławkach w parku

i ze sposobu, w jaki siedzą

i patrzą

widzę że urok minąl [idem 2004: 259].

Bezosobowość znika tutaj pod warstwą poetyzmów, które wprowadzają obcą oryginałowi melancholię, a także łamią pewną właściwą

3 Wszystkie wyróżnienia w cytatach z poezji Bukowskiego pochodzą od autora artykułu. 
Bukowskiemu postawę - jego poezja żywi się wszelkimi przejawami rozpadu, rozpaczy i wulgarności, lecz równocześnie autor zatrzymuje się zawsze na ich powierzchni: odmawia sobie prawa do dokonywania jakichkolwiek arbitralnych ocen i wiwisekcji cudzego, a więc nieprzekładalnego doświadczenia. Stąd bierze się celowe zawoalowanie przyczyny tytułowego zaniku marzeń. W tym samym fragmencie warto zresztą zwrócić uwagę na nieprzetłumaczalną chyba grę językową, która powstaje na skutek etymologicznego wywodzenia się słowa waitress (kelnerka) od czasownika to wait (czekać). Wiersz ukazuje bowiem najgłębszą daremność wszelkiego oczekiwania. Niestety, w polskim języku brakuje odpowiednika leksykalnego, dzięki któremu odsłoniłby się ów głębszy związek starych pracownic kawiarni z czasem-pożercą.

Tom Plonac $w$ wodzie, tonac $w$ ogniu [ibidem] zawiera również piękny liryk Palm Leaves, przełożony przez Madeja jako Liście palmy. Początek oryginału tego wiersza brzmi:

at exactly 12:00 midnight

1973-74

Los Angeles

it began to rain on the

palm leaves outside my window

the horns and firecrackers

went off

and it thundered [idem 1974: 232].

Madej tłumaczy ów początek następująco:

dokładnie o północy

z 1973 na 1974

w Los Angeles

zaczął padać deszcz

na liście palmy za moim oknem

wystrzeliły petardy i zatrąbiły klaksony

niebo zagrzmiało [idem 2004: 262].

Widać tutaj wyraźnie, że kiedy Bukowski informuje czytelnika o czasie i miejscu opisywanego zdarzenia, celowo unika przyimków, nadając całej frazie podobieństwo do urzędowego sposobu zapisu dat, co ma głęboki sens w kontekście późniejszego, kontrastowego fragmentu wiersza: 
New Year's Eve always terrifies

me

life knows nothing of years

Piotr Madej w swoim przekładzie nie zachowuje tej obcej naturze abstrakcyjności i używa przyimków (w, na, za), psując oryginalny efekt. Tymczasem w dalszym ciągu strofoidy i wiersza Bukowski pogłębia jeszcze bezosobowość opisywanych zjawisk, uciekając się do powtórzeń zaimka it (,,it began to rain"; ,it thundered”). Polski tłumacz natomiast poetyzuje: ,zaczął padać deszcz”, ,niebo zagrzmiało”. W ten sposób wbrew oryginałowi nadaje zjawiskom pogodowo-ludzkim niepożądaną osobowość i gubi ich nieokreślony charakter. A jest to istotne, gdyż następna strofoida wiersza zdradza, że bohater przysłuchuje się im z zamkniętego pokoju, nie widzi ich.

Madej nie jest bynajmniej jedynym tłumaczem, na którego Liście pal$m y$ zastawiły przekładową pułapkę. Bardzo interesujący rosyjski przekład tego wiersza sporządził Aleksiej Władimirowicz Karakowski, urodzony w 1978 roku pieśniarz, jazzman i pisarz, laureat wielu prestiżowych nagród oraz autor kilku tomów wierszy i książek prozą ${ }^{4}$. Karakowski przełożył pierwszą zwrotkę Palm Leaves tak:

rovno $\mathrm{v} 12.00$

v noč' s 1973 na 1974

v Los-Andželese

dožd' načal stučat'

po pal'movym list'jam za moim oknom

sireny i migalki

ezdili po gorodu

i gremeli [idem 2004-2012].

Dosłowny przekład jego tłumaczenia brzmiałby następująco:

równo o 12.00

w noc z 1973 na 1974

w Los Angeles

deszcz zaczął stukać

4 Więcej informacji na temat życia i twórczości rosyjskiego thumacza znaleźć można na stronie internetowej https://www.netslova.ru/karakovski/. 
po palmowych liściach za moim oknem

syreny i koguty

jeździły po mieście

i grzmiały ${ }^{5}$

Karakowski popełnił zatem identyczny błąd w tłumaczeniu daty co Madej, a także dokonał jeszcze głębszych zmian w układzie strofoidy oraz przesunięć semantycznych idących w kierunku swobodnej adaptacji. Przede wszystkim deszcz u niego stuka (,dožd' načal stučat'”), co w stosunku do wiersza Bukowskiego jest zdecydowanie za bardzo namacalne i oswojone. Amerykański poeta nie przypadkiem pod sam koniec wiersza przywołuje to samo słowo: rain (tym razem jako rzeczownik), pisząc ,,all I hear is the rain on the palm leaves". Otóż sytuacja opisana w liryku zasadza się na wręcz atawistycznej opozycji samotnego, zamkniętego, przestraszonego człowieka wobec groźnej niedookreśloności świata dźwięków pochodzących z zewnątrz, z natury i cywilizacji. Najciekawsze jest jednak u rosyjskiego tłumacza zasadnicze przesunięcie semantyczne na rzecz specyficznej domestykacji à la russe. Otóż w swoim przekładzie Karakowski zmienia czysto egzystencjalny strach oryginału we wrażenie swoistego zaszczucia bohatera, jak gdyby ten był ścigany, najpewniej przez jakieś władze państwowe. Zamiast banalnych petard i klaksonów mamy tutaj frazę ,sireny i migalki / jezdili po gorodu / i gremeli” (syreny i policyjne koguty jeździły po mieście i grzmiały). Kiedy w drugiej strofoidzie wiersza Bukowski pisze:

I'd gone to bed at 9 p.m.

turned out the lights

pulled up the covers -

Karakowski celowo przenosi czas ułożenia się głównego bohatera do snu z dziewiątej wieczór na dziewiątą rano (,ja pošël spat' v devjat' utra" - poszedłem spać o dziewiątej rano) i to przejście od małej grozy Los Angeles do policyjnej rzeczywistości kojarzącej się z Rosją wydaje się bardzo interesującą próbą przetransponowania całej sytuacji grozy w realia innej kultury.

$5 \quad$ Tekst tłumaczeń Karakowskiego poddano w transliteracji. Wszystkie przekłady rosyjskiego tekstu Karakowskiego w pochodzą od autora artykułu. 
Te zabiegi domestykacyjne powodują jednak problemy z przekładem dwóch charakterystycznych point wiersza. Najpierw w oryginale znajdują się następujące, przytoczone już wyżej słowa:

New Year's Eve always terrifies

me

life knows nothing of years.

Zauważmy, że są one oddzielnymi zdaniami, a drugie z nich ma wyraźnie gnomiczny charakter i strukturalnie łączy się ze sztucznym charakterem daty, od której rozpoczyna się cały wiersz. Piotr Madej przełożył je jako, „życie nie ma pojęcia o latach", choć może trafniej byłoby użyć tutaj drobnej semantycznej modulacji i napisać, że życie nie zna takiego pojęcia jak rok. Karakowski jednak łączy te dwa odrębne człony wiersza w całość składniową

kanun Novogo Goda

vsegda užasaet menja -

žizn' znaet, skol'ko let

(wigilia Nowego Roku

zawsze mnie przeraża -

życie wie, ile lat)

Przez to stwarza wrażenie permanentnego charakteru grozy otaczającej głównego bohatera, lecz gubi ważny element awangardowej poetyki Bukowskiego - ową pierwszą, głucho brzmiącą i niemal filozoficzną pointę.

Kolejna z point definitywnie zamyka wiersz:

6 Co ciekawe, zarówno Karakowski, jak i Madej wtłoczyli w jeden wers ważne słowo „me”, które w oryginale nie bez powodu zajmuje osobny wers. Bukowski świetnie opisuje w ten sposób fenomen grozy, która najpierw pojawia się jako coś całkiem uogólnionego, a potem całkowicie osobistego, wypełniającego ja. 
and I think,

I will never understand men,

but I have lived

it through.

Karakowski tłumaczy ją tak oto:

i ja zadumyvajus' o tom,

čto nikogda ne pojmu ljudej,

no ja uže proehal

èto.

i ja zastanawiam się nad tym

że nigdy nie zrozumiem ludzi

ale ja już przeszedłem

to

Wybrany przez niego zwrot ,ja uže proehal / èto" w potocznej ruszczyźnie może oznaczać „udało mi się tego uniknąć”, „ominęło mnie coś” i odnosi się zwłaszcza do nieszczęścia lub niebezpieczeństwa. Jako że przytoczona już fraza „migalki / jezdili po gorodu” łączy się tu z czasownikiem ,proehal”, tworząc łatwą do zauważenia sieć kohezji tekstowej, całość współgra z atmosferą wprowadzaną przez syreny i policyjne koguty. Nie jest to, rzecz jasna, atmosfera Los Angeles początku lat siedemdziesiątych. Lecz nawet jeśli uznać, że użyty tutaj ekwiwalent rosyjski jest trafny na poziomie signifiant, to okazuje się jego dokładną odwrotnością na poziomie signifié: mówi bowiem o przeżyciu przez uniknięcie czegoś, tymczasem angielskie „lived it through” sugeruje aktywne przejście przez niebezpieczeństwo. Polisystem kultury rosyjskiej za kanoniczne uznaje w tym miejscu raczej próby uniknięcia niebezpieczeństwa, jego biernego przeczekania. Pozostaje jednak otwarte pytanie, na ile tego rodzaju podejście kulturowe do zjawiska odpowiada postawie Bukowskiego. Warto zwrócić uwagę na to, że jest ona peryferyjna nawet w obrębie polisystemu amerykańskiej kultury, w której kanoniczne podejście do sposobu postępowania w razie niebezpieczeństwa polega raczej na zmierzeniu się z nim wprost (by przytoczyć słynny wers Roberta Frosta: „the best way out is always through"), co ma w sobie wiele z lokalnego mitu pionierstwa i wspomnianego już religijnego imperatywu poszukiwania znaków zbawienia. Bukowski nie wpisuje się w tak rozumianą dzielność. 
Jego postawę można by raczej nazwać monadyczną introspekcją, w której podkreśla się nieprzekazywalność doświadczenia między podmiotem lirycznym a wszystkim, co wobec niego zewnętrzne, czy chodzi o starzejące się kelnerki, czy o deszcz i hałaśliwych ludzi na ulicach podczas święta. W strofoidzie:

\section{and I think,}

I will never understand men,

but I have lived

it through.

szczególnie istotne wydaje się skontrastowanie zaimków osobowych: trzykrotnie powtórzonego $I$ oraz wieńczącego myśl it, o którym trudno jednoznacznie powiedzieć, do czego się odnosi. Gramatyka języka angielskiego sprawia, że wyrażenia te wydają się brzmieć zupełnie naturalnie. Wskutek tej zwodniczej naturalności znamienne, a ważne przecież nagromadzenie ja oraz enigmatycznego to może łatwo zginąć w przekładzie na język skłonny do opuszczania podmiotu, taki jak rosyjski czy polski. U Karakowskiego ten problem został dostrzeżony, toteż zaimek ja pojawia się $\mathrm{w}$ jego thumaczeniu dwa razy $\mathrm{i}$ jest skonfrontowany $\mathrm{z}$ finalnym eto. U Madeja natomiast nie występuje ani razu, a zagadkowe it też się nie pojawia:

i myślę, że

nigdy nie zrozumiem ludzi

ale udało mi się przeżyć [idem 2004: 262].

W ten sposób przekład polski nie uwidacznia najbardziej awangardowych wyznaczników pozornie mało skomplikowanej poetyki Bukowskiego.

Specyficzne usytuowanie dzieł i indywidualności Bukowskiego w polisystemie amerykańskiej kultury jest, jak widać, bardzo trudne do adekwatnego oddania w przekładach, gdyż kultury docelowe w zaprezentowanych tłumaczeniach nie żywią się tą samą grą postaw wobec lęku, niebezpieczeństwa, przemijania i śmierci. Objawia się to zwłaszcza w tych wierszach poety, w których przedstawia on nader złożone gry między fizyczną i metafizyczną aktywnością a receptywną pustką i zastygnięciem. Dla Madeja i Karakowskiego zetknięcie się z tak osobliwą i, wbrew pozorom, wymagającą poetyką wiersza okazało się nie lada wyzwaniem. W tej konfrontacji rosyjski tłumacz wypadł nieco lepiej, 
ponieważ trafniej odczytał właściwe intencje autora i nie wahał się umieścić wielu elementów swojego przekładu bliżej kultury docelowej, nie zapominając jednak przy tym o zachowaniu kluczowych elementów, dzięki którym Bukowski pozostaje poetą prawdziwie awangardowym i osobnym na gruncie kultury amerykańskiej.

\section{Bibliografia}

Baran, M. (2005), „Pisarz nałogowy albo testament białego wieloryba”, [w:] Charles Bukowski, Z obłędu odsiać stowo, wers, drogę. Nowe wiersze (thum. Michał Kłobukowski), Noir sur Blanc, Warszawa, 435-446.

Bukowski, C. (1974), Burning in Water, Drowning in Flame, Black Sparrow Press, Santa Rosa, California.

Bukowski, C. (2003), Miłość to piekielny pies. Wiersze z lat 1974-1977 (thum. Leszek Engelking), Noir sur Blanc, Warszawa.

Bukowski, C. (2004), Ptonqc w wodzie, tonac w ogniu. Wiersze z lat 1955-1973 (thum. Piotr Madej), Noir sur Blanc, Warszawa.

Bukowski, C. (2004-2020), „Пальмовые листья”, [w:] Поколение Битников (thum. Алексей Караковский), Георгий Жердев, red. [online] www.netslova.ru/karakovski/ppb.html, 12.06.2020.

Bukowski, C. (2005), Z obłędu odsiać stowo, wers, drogę. Nowe wiersze (thum. Michał Kłobukowski), Noir sur Blanc, Warszawa.

Doroszewski, W. (1958-1969), Stownik języka polskiego pod red. W. Doroszewskiego, [online] https://sjp.pwn.pl/doroszewski/awangardowy;5410757.html, 1.07.2018.

Etymonline, [online] https://www.etymonline.com/search?q=experiment, 1.06.2020.

Jarniewicz, J. (2004), „Horyzontalne wiersze Charlesa Bukowskiego”, [w:] Charles Bukowski, Ptonac w wodzie, tonac w ogniu. Wiersze z lat 1955-1973 (tłum. Piotr Madej), Noir sur Blanc, Warszawa.

Lexico, [online] https://en.oxforddictionaries.com/definition/avant-garde, 1.06.2020.

Madej, P. (2018), Informacja biograficzna, [online] http://cia.media.pl/zmarl_ piotr_madej, 1.07.2018.

Munday, J. (2001), Introducing Translation Studies. Theories and Applications, Routledge, London.

Nerczuk, Z. (2006), „Ataraksja”, [w:] Jan Hartman, red. Stownik filozofii, Zielona Sowa, Kraków, 22. 
Plichta, P. (2013), „O sztuce przekładania ostrych polemik wewnątrzkulturowych i filozoficznych, czyli o udanych i nieudanych przekładach wierszy Roberta Frosta na język polski”, [w:] Piotr Fast, Wacław Osadnik, red. Przekład - kolonizacja czy szansa?, Śląsk, Katowice, 155-164.

Słownik języka polskiego PWN, [online] https://sjp.pwn.pl/szukaj/awangardowy. html, 1.07.2018.

Sounes, H. (2010), Charles Bukowski. Locked in the Arms of a Crazy Life, Canongate, London-Melbourne.

Stachniewski, J. (1991), The Persecutory Imagination. English Puritanism and the Literature of Religious Despair, Clarendon Press, London.

\section{STRESZCZENIE}

Poetykę wierszy Charlesa Bukowskiego można uznać za awangardową nie tylko z powodu ich skandalicznej i często skatologicznej treści. Wypływa ona również z filozoficznej fascynacji autora rozpadem i bezwzględnością czasu, a także sytuacją monadycznego odosobnienia jednostki, odseparowania się od bytów wobec niej zewnętrznych. To zaś sprawia, że nawet w obrębie polisystemu amerykańskiej kultury Bukowski pozostaje zjawiskiem peryferyjnym i osobnym - przekładanie jego liryków wiąże się z nieuniknionymi przesunięciami w obrębie polisystemu kultury docelowej, a przy tym wymaga wnikliwej analizy poetyki tekstu oryginalnego. Artykuł ten dotyczy analizy polskich i rosyjskich thumaczeń dwóch wierszy Bukowskiego (Bez snu i Liście palmowe), zwraca szczególną uwagę na kwestię przekładu bezosobowych fraz i point tekstowych.

Słowa kluczowe: Charles Bukowski, awangardowość, przekład

\section{SUMMARY}

Elements of Avant-garde Poetics and Aesthetics in the Polish and Russian Translations of Charles Bukowski's Poems

The poetics of Charles Bukowski's lyrical verse can be considered avantgarde not only because of their scandalous and often scatological content. It also stems from the author's philosophical fascination with the disintegration and ruthlessness of time, as well as the situation of the monadic 
isolation of the individual from the beings external to him. This, in turn, makes Bukowski a peripheral and separate phenomenon even within the polysystem of American culture: the translation of his poems is associated with inevitable shifts within the polysystem of the target culture and, at the same time, requires an in-depth analysis of the poetics of the original text. This article deals with the analysis of Polish and Russian translations of Bukowski's two poems (Dreamlessly and Palm Leaves), paying particular attention to the issue of translating impersonal phrases and textual points.

Keywords: Charles Bukowski, avant-garde, translation 